\title{
Review on Effect of Climate Change on Forest Ecosystem
}

\author{
Marshet Nigatu Gebeyehu* and Fekadu Hailu Hirpo \\ Natural Resource Management Specialized in Forest and Nature Management, Jimma University, Ethiopia
}

Submission: February 14, 2019; Published: February 28, 2019

*Corresponding author: Marshet Nigatu Gebeyehu, Natural Resource Management Specialized in Forest and Nature Management, Jimma University, Jimma, Ethiopia

\begin{abstract}
Climate change is one of the world's greatest challenges and creates effects on forest ecosystem. Forest ecosystems are sensitive to climate thus; climate change has significant effects on species distributions, the growth rate and structure of forests. Changes in climate are strongly affect forest ecosystem by altering the growth, mortality and reproduction of trees. Increasing temperatures changes the timing of life cycle events (phenology), with earlier bud burst, leafing and flowering in trees. This review focuses on the effect of climate change on forest ecosystems. Climate change alters and shifts forest ecosystems both directly and indirectly. Warming temperature directly affects rate of plant photosynthesis and respiration processes, also indirectly by increasing the risk of infestation. Climate change can modify disturbance regimes that affect the carbon cycle, forest structure, species composition, and alter forest ecosystem function. Disturbances such as fire, species invasions, insect and disease outbreaks are disrupting the structure, composition and function of forest ecosystem. Fire effect on forest ecosystem includes; disturbance of wild life habitat, acceleration of nutrient cycling, and mortality of individual trees. The frequency, size, intensity, seasonality, and type of fires depend on the amount and frequency of precipitation in addition to forest structure and composition. Many pests and pathogens will reproduce more quickly, expand their ranges and invade new regions under warmer, wetter, or carbon dioxide enriched conditions. Increasing temperature has an effect on nutrient availability in the soil through the stimulation of organic matter decomposition and mineralization of soil nutrients.
\end{abstract}

Keywords: Carbon, Climate change, Climate-change effects, Disturbance, Forest ecosystems.

\section{Introduction}

Climate is the primary force shaping the major biomes (such as forests, grasslands, etc.) of the world [1]. The world's climate is changing, thus changes in the climate are likely to strongly affect forest ecosystems by altering the growth, mortality and reproduction of trees. Ecosystem services (supporting, regulating, provisioning and cultural services) are the benefits people derive from the natural processes that sustain ecosystems. These ecosystem services comprise both goods and processes are currently affected by climate change. At present global climate change shows a general increase in temperatures and levels of atmospheric carbon dioxide as well as changes in precipitation. The host physiology and defenses, relationships between pests, their environment and other species such as natural enemies, competitors and mutualists are affected when climate changed [2]. Climate variation produces detectable effects on tree and sapling growth in natural forests.

Warmer temperatures change the timing of life cycle events (phenology), with earlier bud burst, leafing and flowering in trees, although there is much year-to-year and regional variation. It will affect forests also indirectly by increasing the risk of infestation [3]. Effects of climate change on forest ecosystems mainly address the role of the latter with regard to carbon emission and sequestration [4]. It also alters the frequency and/or severity of natural disturbances in some forests, particularly fire and insect disturbances. In many forest ecosystems disturbance regimes have changed in recent years and expected to be among the most profound effect that climate change will have in the coming decades [5].

Increases in disturbance severities could have dramatic effect on forest ecosystem structures, species composition, and their ability to act as carbon sinks [4]. Disturbances such as fire, drought, species invasions, insect and disease outbreaks, and storms such as hurricanes are disrupting the structure, composition and function of forest ecosystem, community or population, and change resource availability or the physical environment. There is evidence resulting in increased forest damage, erosion and landslides, with wetter soils and flooding over the last century [6]. Climate change can affect nutrient cycling directly through its impact on temperature and precipitation. The productivity and integrity of forest ecosystems is linked to the supply of nutrients and climate change can influence nutrient dynamics by altering the rate of litter decomposition.

The potential of ecosystems to take up carbon is constrained by the availability of nitrogen and it is a basic element that is 
fundamental to the growth of plants. Nitrogen limits forest growth under most conditions. Too much nitrogen, however, can have detrimental effects on soil, trees, or indirectly through its impacts on forest composition, growing season length, and the water cycle. The major objective of this paper is to collate and review much of the current information and scientific -literature on the effect of climate change on forests and forest ecosystems.

\section{Methodology}

This paper comprises a review of literature regarding climate change effect on forest ecosystem and reviewed research progresses about climate change effect on forest ecosystem in the past 14 years.

\section{Climate Change Effect on Forest Ecosystem}

\section{Forest disturbances under climate change}

Climate change can modify a disturbance regime that affects forest ecosystem structure and function. The change in forest structure and function are disrupted when disturbances exceed their natural range of variation. Natural disturbances, such as fires, insect outbreaks and wind throws are an integral part of ecosystem dynamics in forests around the globe. Warming climates pose significant threats to forest ecosystems [4]. It may increase mortality in older forests stressed by low soil moisture.

A gradual increase in temperature will alter the regeneration and growth of some species. Regeneration of tree species is affected by low soil moisture and competition with other species during the seedling stage as the temperature increase. Climatic variability and change results degradation of the forest resources to emission of carbon dioxide in the atmosphere and affecting the forest resources and its ability to deliver its ecosystem services [7].

\section{Fire}

Increases in temperatures create conditions that dramatically elevate the risk and severity of forest fires. Fire effect on forest ecosystem includes; disturbance of wild life habitat, acceleration of nutrient cycling, and mortality of individual trees. The frequency, size, intensity, seasonality, and type of fires depend on the amount and frequency of precipitation in addition to forest structure and composition. Fire is a major control of forest carbon balance and reduces the strength of forests carbon sinks [8]. The forest wildfires loss most soil nutrients and it has effect on the available macronutrient concentrations.

Climate change is increasing the likelihood of fire ignition and propagation such as, extreme temperatures and plant biomass accumulation, but these are possibly interacting with socio-economic factors [9]. Forest fires directly a loss of habitat, kill plants and animals in forest ecosystem. The potential for prescribed fire to mitigate nitrogen saturation resulting from atmospheric deposition and disturbances that can cause comparable nutrient loss in such a short amount of time [10].

\section{Invasive species}

Climate change will have the effect of increasing the extent, frequency, and severity of invasive species, as well as facilitating a shift toward invasion in species that have not historically been invasive. It creates a favorable condition for invasive species to invade the forest ecosystem. The removal of temperature or moisture constraints to dispersal and survival lead to changes in the distributions of species and successfully invade new areas [11]. Species range shifts will also lead to becoming rare and creates ecological space for non-native invasive species to increase in abundance and move in. Invasive species show a greater response to increased carbon dioxide than non-invaders. Invasive species have strong dispersal abilities and broad environmental tolerances, which will allow them to cope with rapid changes.

Invasive plants are recent introductions of non-indigenous or exotic species that are successfully spread into new localized natural habitats to cause economic or environmental harm. Change in weather events increases the disturbance regime, and invasive species generally, thrive in disturbed landscapes with high light availability and fragmented native communities [12].

\section{Change effect on forest health}

Forest ecosystem pests and pathogens are likely to increase, either through the direct effect of climate change on their abundance or distribution, or the indirect effect of increased water stress or wind damage which will increase the susceptibility of trees to attack. Climate change alter the disturbance dynamics of native forest insect pests and pathogens, as well as facilitating the establishment and spread of non-indigenous species [2]. Pathogens can take advantage of changing climate; it could have major effects on tree health and survivorship [13].

Forest pathogens may be viral, bacterial or fungal, viral or bacterial infection and transmission rates seem to vary with temperature and moisture in the forest ecosystem. Pathogens like fungal can survive and remain infective over a wide range of temperatures. However, the conditions that favor epidemic growth for most fungal pathogens are constrained to within a band of a few degrees Celsius.

\section{Incident of pests and disease}

Climate change increased the extent of greater insect overwinter survival, shortened reproduction cycles and development [14]. Insects and pathogens have been noted to respond to warming in all the expected ways, from changes in phenology and distribution to influencing community dynamics and composition [2]. Incidence of pests and diseases may increase with climate variability and climate change. With long dry spells and more intense rainfall, the resulting decline in water quality will lead to greater risk of waterborne diseases [15]. Invasive forest plants, insects and pathogens can directly cause tree mortality. Increased disturbance in forests was occurred from insects, especially from bark beetles. Trees damaged by insects 
and pathogens can have substantial socioeconomic effects because of their high physiological sensitivity to climate, short generation times, high mobility, and explosive reproductive potential.

Many pests and pathogens will reproduce more quickly, expand their ranges and invade new regions under warmer, wetter, or carbon dioxide enriched conditions. Insect pests are sensitive to a warming climate under greater moisture or temperatures stress their survival and reproductive rate. Climate change cause tree pest and pathogen outbreak that can have negative economic and environmental impacts [16]. A highly virulent pest can lead to significant changes in forest structure and species composition especially decimate populations of susceptible tree species [17].

\section{Effects of climate change on forest processes}

Trees require light, heat carbon dioxide and water nutrient to grow through the process of photosynthesis. Increasing temperature, atmospheric carbon dioxide concentrations are altering photosynthesis rates and growth. Naturally plants have their own mechanism to tolerate a certain level of increased temperature. Soil decomposition rate of organic matter will increase as temperature increase and then nutrient mineralization and availability for plants uptake become increased. Thus, the interaction and different combination effect of rise carbon dioxide concentration and temperature is determined by soil properties, water, mineral and nutrient availability.

The availability of forest resources will determine whether a tree will grow well or not, altering the balance between growth and mortality and therefore determining forest productivity [5]. Increase temperature, precipitation, and carbon dioxide alter carbon balance over longer time and affect nutrient cycling directly or indirectly through its impacts on forest composition, growing season length, and the water cycle [18].

\section{Changes in nutrient availability}

Increasing temperature is likely to affect nutrient availability in the soil through the stimulation of organic matter decomposition and mineralization of soil nutrients. There are important links between trees and soil nutrient availability. The cycling of nutrients between the soil and plants is one of the main factors of forest ecosystem functioning. Climate change affect availability of nutrients for plant uptake and limit the productivity, survival of forest ecosystems. Nutrient availability affects forest ecosystem and net primary productivity [19]. On the forest floor organic matter that broken down by microbes such as down fallen leaves release nitrogen to the soil.

Increasing the nitrogen demand is essential for plant the growth, development and builds protein however, increasing carbon dioxide levels in the atmosphere more microbes are becoming nitrogen limited and releasing less nutrients to the trees. The productivity of forest ecosystem appears to be controlled by quantity and availability of nutrient. Warming temperature has direct physiological effects on rate photosynthesis, macronutrient concentration in soils and leaves of tree, shrubs and herbs. Increase in temperature can lead to reductions in nutrient availability [20].

\section{Conclusion}

Climate change is one of the world's greatest challenges. At present global climate change shows a general increase in temperatures and levels of atmospheric carbon dioxide as well as changes in precipitation. It creates effects on forest ecosystem. Climate change affect ecosystem service comprises both goods, process and it poses major new challenges to forest ecosystem. Forest ecosystems are sensitive to climate thus; climate change has significant effects on species distributions, the growth rate and structure of forests. This paper reviewed research progresses about climate change effect on forest ecosystem. The changes in the climate are likely to strongly affect forest ecosystems by altering the growth, mortality and reproduction of trees. Forest ecosystems are sensitive and subjected to climate change produce detectable effects on tree and sapling growth in natural forests. Climate change particularly facilitates drought, fire and insect disturbance; thus, changes increase carbon dioxide concentration, reduce the strength of carbon sinks and may turn carbon sink into source. Forest fires directly a loss of habitat, kill plants and animals in forest ecosystem.

Climate change can create a favorable condition for invasive species to invade the plant ecosystem. Invasive plants are recent introductions of nonnative, exotic, or non-indigenous species that are successfully established or naturalized and spread into new localized natural habitats to cause economic or environmental harm. Effect on forest health and forest properties with larger changes in temperature and precipitation will affect forest ecosystem more strongly. Forest ecosystem pests and pathogens are likely to increase either through the direct effect of climate change on their abundance or distribution or the indirect effect of increased water stress or wind damage which will increase the susceptibility of trees to attack. Different literature suggests that global forest ecosystem disturbance such as invasive species; insects and pathogens in particular are likely to increase in a warming world. Increasing temperature is likely to affect nutrient availability in the soil through the stimulation of organic matter decomposition and mineralization of soil nutrients.

\section{Recommendation}

Actively managing forest ecosystem to improve forest structure, function, diversify tree species, and increase resilience to climate change. Community awareness programs on effective forest conservation, reforestation and afforestation can be used an effective tool to cope with the increasing effect of climate change on forest ecosystem. Increasing alternative livelihood and using forest resource in sustainable way. Information and tools need to be available to make decisions in solving climate change effect on forest ecosystem. In order to tackle climate 
change challenges on forest ecosystem, it is important to provide capacities and support to the forest sector. There is also a need for alternative practices to reduce subsequent vulnerability of forests ecosystem, such as planting genetically tolerant trees identified through breeding programs. Most of the Literatures discussed only the effect of climate change on forest and related ecosystem rather than discussing the solution for so, it's important to put the solution and action to solve the problem rather than writing only the effects and constraints.

\section{Acknowledgement}

We would like to thank Instructor Desalegn Obsi from Jimma University for his support.

\section{References}

1. LSMOH (2012) Medium-Term Sector Strategy (MTSS) 2013 - 2015, p. 125.

2. Moore B, Allard G (2008) Climate change impacts on forest health, Forest health and biosecurity working papers FBS/34E, p. 39.

3. Zhu Z (2018) Coherence relative to a weak torsion class. Czechoslovak Mathematical Journal 68(2): 455-474.

4. Battles JJ, Robards T, Das A, Waring K, Gilless JK, et al. (2008) Climate change impacts on forest growth and tree mortality. Climatic Change 87(Supp 1): s193-s213.

5. Seidl R, Thom D, Kautz M, Martin-Benito D, Peltoniemi M, et al. (2017) Forest disturbances under climate change. Nature Climate Change $7(6)$ : 395-402.

6. Wu J, Van Der Linden L, Lasslop G, Carvalhais N, Pilegaard K, et al. (2012) Effects of climate variability and functional changes on the interannual variation of the carbon balance in a temperate deciduous forest. Biogeosciences 9(1): 13-28.

7. Lasco RD, Pulhin F, Sanchez P, Villamor GB, Villegas KAL (2008) Climate change and forest ecosystems in the Philippines: Vulnerability, adaptation and mitigation. Journal of Environmental Science and Management 11(1): 1-14.

8. Rice J (2010) Carbon stock conditions and how climate and disturbance may influence carbon dynamics on the Shoshone National Forest, Wyoming, (Ipcc 2007), pp. 1-16.

This work is licensed under Creative Commons Attribution 4.0 License DOI: 10.19080/IJESNR.2019.17.555968
9. Forests T (2006) Forest Fires and climate change in Indonesia. pp. 1-5.

10. Paoletti E, Bytnerowicz A, Andersen C, Augustaitis A, Ferretti M, et al. (2007) Impacts of air pollution and climate change on forest ecosystems - Emerging research needs. ScientificWorldJournal 7 Suppl 1: 1-8.

11. Hellmann JJ, Byers JE, Bierwagen BG, Dukes JS (2008) Five potential consequences of climate change for invasive species. Conserv Biol 22(3): 534-543.

12. (2010) Climate Change and Invasive Species Impacts of Invasive Species on Ecosystems.

13. Rustad L, Campbell J, Dukes JS, Huntington T, Lambert KF, et al. (2012) Changing climate, changing forests: the impacts of climate change on forests of the Northeastern United States and Eastern Canada. Forests $7(12): 56$.

14. Grimm NB, Chapin FS, Bierwagen B, Gonzalez P, Groffman PM, et al. (2013) The impacts of climate change on ecosystem structure and function. Frontiers in Ecology and the Environment 11(9): 474-482.

15. Dinse K (2010) Understanding climate variability and climate change. Michigan Sea Grant Report, pp. 1-25.

16. Macpherson MF, Kleczkowski A, Healey JR, Quine CP, Hanley N (2017) The effects of invasive pests and pathogens on strategies for forest diversification. Ecol Modell 350: 87-99.

17. Lovett GM, Weiss M, Liebhold AM, Holmes TP, Leung B, et al. (2016) Nonnative forest insects and pathogens in the United States: Impacts and policy options. Ecol Appl 26(5): 1437-1455.

18. Ryan MG, Vose JM, Hanson PJ, Iverson LR, Miniat CF, et al. (2014) Climate Change and United States Forests. In: Peterson DL, Vose JM, Weynand TP (Eds.), Advances in Global Change Research 57: 25-54.

19. Langley A (2014) Meetings Using results from global change experiments to inform land model development and calibration Participants expect a weaker $\mathrm{CO}_{2}$ response than models or experimental data would suggest, pp. 744-746.

20. Juneja A, Ceballo RM, Murthy GS (2013) Effects of environmental factors and nutrient availability on the biochemical composition of algae for biofuels production: A review. Energies 6(9): 4607-4638.

Your next submission with Juniper Publishers will reach you the below assets

- Quality Editorial service

- Swift Peer Review

- Reprints availability

- E-prints Service

- Manuscript Podcast for convenient understanding

- Global attainment for your research

- Manuscript accessibility in different formats

( Pdf, E-pub, Full Text, Audio)

- Unceasing customer service

Track the below URL for one-step submission https://juniperpublishers.com/online-submission.php 